\title{
Reply to McKibbin and Robson
}

\section{John Quiggin}

Warwick McKibbin makes a number of important points in his contribution. First, given that we have taken no effective action for a decade, the Task Group timeline for setting up an emissions-trading system by 2012 is excessively relaxed. Second, any credible strategy will require deeper cuts in emissions than those currently being considered.

Unsurprisingly in view of his previous contributions to the debate (McKibbin and Wilcoxen 1997, 2002), McKibbin welcomes the Task Group proposal for a 'safety valve' in the form of a cap on the price of emissions. This proposal raises two kinds of questions.

First, in economic terms, does the risk of excessive short-run economic costs from mitigation outweigh the risk of inadequate mitigation (implying either greater damage from climate change or costly adjustment in the future)?

Second, in political terms, is a price-capped system more likely than a purely rights-based system to form the basis of a sustainable global agreement?

As I noted in my assessment of the Working Group, the conditions under which the Group was set up presupposed the hypotheses that the Kyoto process would necessarily fail, and that the economic costs of mitigation should be the primary concern. Under these assumptions, a price-capped approach is optimal. In my view, however, the Kyoto process is the best hope for an agreement and should be pursued.

Alex Robson's piece begins with a description of the greenhouse effect, and on the relative contribution of anthropogenic and natural activity. It ends with the observation that: 'The annual flow of carbon dioxide into the atmosphere resulting from human activities (fossil-fuel burning and land-use change) is just over $7 \mathrm{GtC}$. This is just over 3 per cent of the natural annual gross flows, and less than 1 per cent of the total atmospheric $\mathrm{CO}_{2}$ stock.' It is unclear what inference is intended here, but, in view of Robson's previous contributions on the topic (Davidson and Robson 2007), it seems reasonable to interpret this as an attempt to cast doubt on the scientific basis for attributing climate change to $\mathrm{CO}_{2}$ emissions. If this is the intention, the effort is unsuccessful. Obviously, a net addition equal to 1 per cent of (initial) stocks of atmospheric $\mathrm{CO}_{2}$ will double the stock in 100 years. A more sophisticated version of this calculation is offered by the IPCC.

In casting doubt on human responsibility for climate change, Robson sets the stage for his main argument which is that, even if humanity as a whole is 
responsible for climate change, there is nothing Australia can or should do about it. The central argument is a classic presentation of the case for being a free-rider. Since Australia contributes only 1.5 per cent of emissions, the impact on Australia of any change in our own emissions is small, and therefore we should focus on damage mitigation

The free-rider problem has been studied extensively. The literature yields two central points, neither of which is addressed by Robson. First, when there are many players, the same arguments apply to all, and the free-rider equilibrium is globally suboptimal. Second, free-riding may be deterred if other players punish defectors. In this case, it is necessary to consider both the possibility of directly punishing free-riding through border taxes or indirect punishment in other negotiating forums

Unfortunately, rather than drawing on the large game-theoretic literature that has arisen in relation to this question, Robson frames the analysis in terms of policy choices for a small open economy. Of course, the fact that Australia is small is relevant to free-riding. But in practice, every participant in this process — including relatively large countries, the US and China - is subject to the same logic. As regards openness, this makes free-riding less appealing, not more, since it generates many more opportunities for other parties to punish us for a policy that would rightly be regarded as deserving of such punishment.

\section{References}

Davidson, S. and A. Robson 2007, 'IPCC pulls numbers out of thin air', Australian Financial Review, 2 April, 〈http://www.ipa.org.au/files/news_1342.html〉

McKibbin, W. J. and P. Wilcoxen 1997, ‘A Better Way to Slow Global Climate Change', Brookings Policy Brief 17, June, The Brookings Institution, Washington.

2002, Climate Change Policy After Kyoto: A Blueprint for a Realistic Approach, The Brookings Institution, Washington. 